\title{
Inflammatory Bowel Disease-Associated Interleukin-33 Is Preferentially Expressed in Ulceration-Associated Myofibroblasts
}

\author{
Jon Sponheim, ${ }^{* \dagger}$ Jürgen Pollheimer, ${ }^{\dagger \neq}$ \\ Trine Olsen, ${ }^{\S}$ Johanna Balogh, ${ }^{\dagger \neq}$ \\ Clara Hammarström, ${ }^{\ddagger}$ Tamara Loos, ${ }^{\dagger \neq}$ \\ Monika Kasprzycka, ${ }^{\text {ॠ }}$ Dag Reidar Sørensen, ${ }^{\text {"ा }}$ \\ Hogne Røed Nilsen, ${ }^{\dagger \ddagger}$ Axel M. Küchler, ${ }^{\dagger \ddagger}$ \\ Morten H. Vatn," and Guttorm Haraldsen ${ }^{\ddagger \dagger}$ \\ From the Department of Internal Medicine," Asker and Baerum \\ Hospital, Vestre Viken Hospital Trust, Rud; the Institute of \\ Pathology, ${ }^{\dagger}$ Faculty of Medicine, and Epi-Gen, ${ }^{\|}$Faculty Division \\ Ahus, University of Oslo, Oslo and the Division of Pathology, ${ }^{\ddagger}$ the \\ Department of Comparative Medicine, "I Oslo University Hospital, \\ Oslo; and the Laboratory of Gastroenterology, Institute of \\ Clinical Medicine, University of Tromsø, Tromsø, Norway
}

Interleukin-33 (IL-33) is a novel member of the interleukin-1 family that induces mucosal pathology in vivo and may drive fibrosis development and angiogenesis. To address its potential role in inflammatory bowel disease, we explored its tissue expression in biopsy specimens from untreated ulcerative colitis patients, observing a 2.6-fold up-regulation of IL-33 mRNA levels, compared to controls. Immunohistochemical analyses of surgical specimens showed that a prominent source of $\mathrm{IL}-33$ in ulcerative colitis lesions were ulceration-associated myofibroblasts that co-expressed the fibroblast marker heat shock protein 47 , platelet-derived growth factor receptor (PDGFR) $\beta$, and, in part, the myofibroblast marker $\alpha$-smooth muscle actin (SMA). In contrast, IL-33-positive myofibroblasts were almost absent near the deep fissures seen in Crohn's disease. A screen of known and putative activators of $\mathrm{IL}-33$ in cultured fibroblasts revealed that the Toll-like receptor- 3 agonist poly (I:C) was among the strongest inducers of IL-33 and that it synergized with transforming growth factor- $\beta$, a combination also known to boost myofibroblast differentiation. Experimental wound healing in rat skin revealed that the de novo induction of $\mathrm{IL}-33$ in pericytes and the possible activation of scattered, tissue-

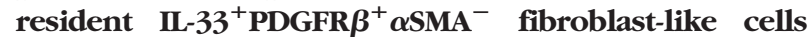
were early events that preceded the later appear-

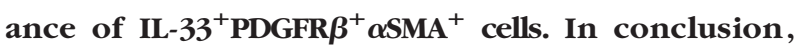
our data point to a novel role for II-33 in mucosal healing and wound repair and to an interesting difference between ulcerative colitis and Crohn's disease. (AmJ Pathol 2010, 177:2804-2815; DOI: 10.2353/ajpath.2010.100378)

Ulcerative colitis (UC) and Crohn's disease (CD) constitute the two major forms of inflammatory bowel disease (IBD) and have a substantial impact on quality of life in a large number of patients worldwide. ${ }^{1}$ The introduction of tumor necrosis factor (TNF) $\alpha$ blocking antibodies has been welcomed as an effective treatment option for these patients, but shows side effects that are not negligible. ${ }^{2,3}$ Moreover, there is a substantial number of nonresponders to anti-TNF treatment, underlining the current opinion that our understanding of the complex cytokine networks active in IBD is far from complete. $^{4,5}$

Interleukin (IL)-33 (C9ORF26, NF-HEV, DVS27, and $\mathrm{IL}-1 \mathrm{~F} 11)$ is a novel member of the $\mathrm{IL}-1$ family which also includes the pro-inflammatory cytokines $\mathrm{IL}-1 \alpha$, IL-1 $1 \beta$, and IL-18. ${ }^{6-8}$ IL-33 was initially associated with the development of T helper (Th)2 immunity, based on the expression of its receptor ST2L (IL-1R4) in polarized Th2 lymphocytes and its ability to induce the production of Th2associated cytokines (IL-5 and IL-13) in vivo. ${ }^{9}$ On the other hand, IL-33 appears to exacerbate arthritis, ${ }^{10,11}$ generally considered to be a Th1/Th17 lesion. Indeed,

Supported by Helse Sør-Øst (2008139 and 2007044), the Norwegian Cancer Society (PK01-2006-0448 and PK01-2007-0199), the Research Council of Norway (133924/300), and the University of Oslo (131406). J.S. and A.M.K. are Ph.D. and Postdoctoral Fellows of Helse Sør-Øst, J.P. and J.B. are Postdoctoral Fellows of the Norwegian Cancer Society.

J.P. and T.O. contributed equally.

Accepted for publication August 17, 2010.

Disclosure: G.H. is inventor of patent WO 2004/056868 A2.

Current address for J.P.: Dept. of Obstetrics and Fetal-Maternal Medicine, Medical University of Vienna, Austria.

Address reprint requests to Guttorm Haraldsen, M.D., Ph.D., Division of Pathology, Oslo University Hospital Rikshospitalet, Oslo, Sognsvannsveien 20, N-0027 Oslo, Norway. E-mail: gharalds@rr-research.no. 
Table 1. Clinical Characteristics of Patient Specimens

\begin{tabular}{|c|c|c|c|c|c|c|c|c|c|c|c|}
\hline & \multirow[b]{2}{*}{$\begin{array}{l}\text { Number } \\
\text { of } \\
\text { patients }\end{array}$} & \multirow[b]{2}{*}{$\begin{array}{l}\text { Sex } \\
(\mathrm{F} / \mathrm{M})\end{array}$} & \multirow[b]{2}{*}{$\begin{array}{l}\text { Age } \\
\text { (mean/ } \\
\text { range) }\end{array}$} & \multirow{2}{*}{$\begin{array}{c}\text { Endoscopic } \\
\text { score } \\
\text { (median/ } \\
\text { range) }\end{array}$} & \multirow{2}{*}{$\begin{array}{l}\text { UCDAI } \\
\text { score } \\
\text { (median/ } \\
\text { range) }\end{array}$} & \multicolumn{3}{|c|}{ Specimen position } & \multicolumn{3}{|c|}{ Histological inflammation grade } \\
\hline & & & & & & Rectum & $\begin{array}{l}\text { Left } \\
\text { colon }\end{array}$ & $\begin{array}{l}\text { Right } \\
\text { colon }\end{array}$ & $\begin{array}{c}\text { Mild } \\
\text { chronic }\end{array}$ & $\begin{array}{c}\text { Moderate } \\
\text { chronic active }\end{array}$ & $\begin{array}{c}\text { Severe } \\
\text { chronic active }\end{array}$ \\
\hline \multicolumn{12}{|l|}{$\begin{array}{l}\text { Biopsy } \\
\text { specimens }\end{array}$} \\
\hline$-U C$ & 25 & $11 / 14$ & $40.0(17-71)$ & $2(0-3)$ & $7(0-12)$ & 15 & 7 & 3 & ND & ND & ND \\
\hline $\begin{array}{l}\text { - Controls } \\
\text { Surgical }\end{array}$ & 22 & $13 / 9$ & $48.5(21-82)$ & 0 & ND & 8 & 7 & 7 & ND & ND & ND \\
\hline - UC & 6 & $1 / 5$ & $42.2(19-77)$ & ND & ND & 2 & 2 & 2 & 0 & 1 & 5 \\
\hline$-\mathrm{CD}$ & 10 & $4 / 6$ & $36.5(20-52)$ & ND & ND & 0 & 1 & 9 & 3 & 3 & 4 \\
\hline - Controls & 6 & $4 / 2$ & $69.3(49-85)$ & ND & ND & 1 & 5 & 0 & 0 & 0 & 0 \\
\hline
\end{tabular}

UC, ulcrative colitis; ND, not determined; CD, Crohn's disease.

ST2L mediates the action of IL-33 on several other leukocyte subsets (reviewed in (ref. no) 8, 12, 13), as well as tissue-resident cells. ${ }^{14,15}$

Despite a large body of evidence describing the effects of recombinant IL-33 and/or the modulation of its receptor, much less is known about the cellular sources and secretion modes of IL-33. Immunohistochemical analysis of healthy organs has revealed that IL-33 expression is restricted to the nuclei of vascular endothelial cells, ${ }^{16,17}$ a subset of epithelial cells and fibroblast-like cells in lymph nodes. ${ }^{17-19}$ In fact, nuclear IL-33 appears to act as a transcriptional repressor ${ }^{20}$ and to bind to nucleosomal proteins, ${ }^{21}$ but how its nuclear function affects cellular behavior remains unknown. Strikingly, while pro-inflammatory IL- $1 \beta$ and TNF $\alpha$ leads to a strong downregulation of IL-33 in endothelial cells, ${ }^{16}$ these cytokines and also ligands to Toll-like receptor (TLR)2, TLR3, or TLR4, as well as mechanical strain, lead to up-regulation or de novo expression of IL-33 in smooth muscle cells, astrocytes, fibroblasts, or hepatic stellate cells. ${ }^{9-11,22-24}$ Accordingly, induction of nuclear IL-33 has been observed in inflamed synovium, in cardiac failure, and in liver fibrosis. ${ }^{11,22,24}$

Low levels of IL-33 have also been found in the supernatant of several cell types $22,23,25,26$ and it can be released from necrotic ${ }^{27}$ and damaged cells. ${ }^{28}$ On the other hand, the mechanisms that allow secretion of IL-33 from intact cells remain unclear (reviewed in 29). Nevertheless, use of recombinant, bioactive IL-33 shows some features of particular interest to the present study: first, daily injections of IL-33 in murine skin leads to the development of cutaneous fibrosis ${ }^{30}$ and second, IL-33 appears to stimulate angiogenesis. ${ }^{14}$

In addition to a need to more fully understand the cytokine network of the intestine, there are several good reasons to map the expression of IL-33 in mucosal inflammation. First, intraperitoneal administration of recombinant IL-33 induced inflammatory infiltrates in the esophagus, hypertrophy of intestinal goblet cells, and increased intestinal mucus. ${ }^{9}$ Second, exogenous IL-33 also facilitated the expulsion of intestinal Trichuris infection, apparently by inducing IL-4, IL-9, and IL-13 and preventing an inappropriate parasite-specific Th1-polarized response. Moreover, infection triggered elevated mRNA levels of IL-33 in cecal tissue. ${ }^{31}$ Finally, while CD is a transmural, granulo- matous, inflammatory process that shows features of Th1/ Th17 disease, ${ }^{4}$ UC is considered an atypical Th2 disease characterized by high levels of $1 \mathrm{~L}-13^{32}$ and shows the pathological features of a more superficial disease in which mucosal damage is an overriding factor. Thus, UC and CD would appear suitable to compare the nature of IL-33 expression in two polarized cytokine environments within the same organ.

Here, we argue that that a prominent feature of IBDassociated IL-33 expression is the accumulation of fibroblasts and myofibroblasts in ulcerations of UC lesions. Moreover, we observed that the strongest single stimulus to induce IL-33 expression was via TLR3, a sensor of viral double-stranded RNA but also of mRNA released from damaged cells ${ }^{33}$ and that TLR3 ligation synergized with TGF $\beta$ to boost the expression of IL-33. Finally, we took advantage of a model of experimental wound healing to discover that pericytes were among the early cell populations to express nuclear IL-33 de novo.

\section{Materials and Methods}

\section{Patient Specimens}

A total of 41 IBD and 28 non-inflamed control (non-IBD) patients were included in the present study according to protocols approved by the Regional Committees for Research Ethics and the Norwegian Social Science Data Services. Endoscopic biopsy specimens from untreated UC patients $(n=25)$ and controls $(n=22)$ undergoing flexible sigmoidoscopy or colonoscopy for diagnostic purposes were used for quantitative PCR analysis. The diagnosis was based on established clinical, endoscopic, and histological criteria. ${ }^{34}$ The indication for colonoscopy in the control group was IBS without diarrhea. Subjects with normal colonoscopy and histology were included. The clinical characteristics of patients and controls are listed in Table 1. The disease activity for the UC patients included in the PCR analyses was evaluated using the scoring system Ulcerative Colitis Disease Activity Index, which is based on clinical signs (score 0-12) and on endoscopic evaluation of the distal colon during colonoscopy (grade 0-3). ${ }^{35}$ Biopsies were taken from the most severely inflamed colonic mucosa and immediately 
Table 2. Table of Primary Antibodies

\begin{tabular}{|c|c|c|c|c|}
\hline Specificity & Clone & Species and subclass & Working concentration & Source \\
\hline IL-33 & Nessy-1 & Mouse IgG1 & $1 \mu \mathrm{g} / \mathrm{ml}$ & Alexis \\
\hline IL-33 & IL-33Nter & Rabbit & $1 \mu \mathrm{g} / \mathrm{ml}$ & Eurogentec \\
\hline IL-33 & AF3625 & Goat & $1: 1000$ & $R \& D$ \\
\hline$\alpha \mathrm{SMA}$ & $1 \mathrm{~A} 4$ & Mouse IgG2a & $1: 100$ & DAKO \\
\hline CD31 & $\mathrm{JC} / 70 \mathrm{~A}$ & Mouse IgG1 & $1: 10$ & DAKO \\
\hline CD34 & QBend/10 & Mouse IgG1 & $1: 100$ & Novocastra \\
\hline CD45 & $135-4 \mathrm{C} 5$ & Mouse IgG2b & $3 \mu \mathrm{g} / \mathrm{ml}$ & LabVision \\
\hline CD45 & $2 \mathrm{~B} 11+\mathrm{PD} 7 / 26$ & Mouse IgG1 & $1: 100$ & DAKO \\
\hline CD68 & PG-M1 & Mouse lgG3 & $1: 100$ & DAKO \\
\hline Cytokeratin & $A E 1 \& A E 3$ & Mouse IgG1 & $1: 20$ & DAKO \\
\hline Cytokeratin & MNF116 & Mouse IgG1 & $1: 100$ & DAKO \\
\hline Desmin & D33 & Mouse IgG1 & $1: 100$ & DAKO \\
\hline HSP47 & sc-5293 & Mouse IgG2a & $1: 200$ & Santa Cruz \\
\hline Mast cell tryptase & AA1 & Mouse IgG1 & $1: 2000$ & DAKO \\
\hline PDGFR $\beta$ & $28 \mathrm{E} 1$ & Rabbit mAb & $0.15 \mu \mathrm{g} / \mathrm{ml}$ & Cell Signaling \\
\hline VE-cadherin & ALX-210-232 & Rabbit & $1: 10,000$ & Alexis \\
\hline Vimentin & 3B4 & Mouse IgG2a & $1: 200$ & DAKO \\
\hline Irrelevant control & MOPC21 & Mouse IgG1 & Concentration matched & Sigma \\
\hline Irrelevant control & $42 / 2$ & Mouse IgG2a & Concentration matched & R. Burns, Edinburgh \\
\hline
\end{tabular}

immersed in RNAlater (Applied Biosystems, Ambion Inc, Austin, TX).

Surgical specimens from patients with either UC $(n=$ $6)$ or $\mathrm{CD}(n=10)$, as well as control specimens obtained from patients who underwent bowel resection for nonmalignant conditions $(n=6)$ were used as a source for immunohistochemical studies. The original pathology examination records of $\mathrm{UC}$ and $\mathrm{CD}$ patients ranged from mild chronic to severe chronic active inflammation (Table 1) and were reexamined by a pathologist (C.H.). Surgical specimens from each IBD patient included areas preferably ranging from mild to severe inflammation. Control samples showed no signs of macro- or microscopic inflammation.

\section{Quantitative PCR Analysis}

The real-time PCR procedures have been described in detail previously. ${ }^{36,37}$ Total RNA was extracted from biopsies according to the Trizol method (Invitrogen, Paisley, UK) and quantified at $260 \mathrm{~nm}$ in a U-1500 UVN is spectrophotometer (Hitachi Instruments Inc, San Jose, CA). RNA integrity was assessed in an Agilent 2100 Bioanalyzer on RNA 6000 Nano chips (Agilent Technology, Böblingen, Germany) according to the manufacturer's instructions and all samples included were found to be $\mathrm{RIN} \geq 8$ (RNA integrity number) on a scale from 0 to 10 . Reverse transcription of total RNA was performed by iScript (Bio-Rad, Hercules, CA) according to the manufacturer's instructions. Levels of mRNA for IL-33 and $\beta$-actin were determined in duplicates by real-time quantitative PCR using TaqMan chemistry (Applied Biosystems, Foster City, CA) and a standardized threshold value. Evaluations of pre-PCR steps and assays have been conducted earlier ${ }^{37}$ showing that the quantitative PCR method discriminates a difference of two samples with a variation of $24 \%$ or more with a probability of 95\% over a $5 \log 10$ range. ${ }^{38}$ Primer sequences: IL-33 fwd: 5' TGAGTCTCAACACCCCTCAAATG 3', IL-33 rev: 5' GGCATGCAACCAGAAGTCTIT 3', IL-33 probe: FAM 5'
CAGGTGACGGTGTTGATGGTAAGATGTTAATG $3^{\prime}$ BHQ: $\beta$-actin fwd: $5^{\prime}$ TGCCGACAGGATGCAGAAG $3^{\prime}, \beta$-actin rev: 5' GCCGATCCACACGGAGTACT 3'; $\beta$-actin probe: FAM 5' CAGGTGACGGTGTTGATGGTAAGATGTTAATG $3^{\prime} \mathrm{BHQ}$. The stability of $\beta$-actin as a housekeeping gene in the present context has been verified earlier. ${ }^{36}$ Cytokine transcript levels relative to those of $\beta$-actin were analyzed according to the comparative $C_{\mathrm{T}}$-method and expressed as $2^{-\Delta C T} \times 10 E 4 .{ }^{39}$ The PCR efficiencies were close to 2 for both the IL-33 and the $\beta$-actin CDNA using serial dilutions of the templates. The laboratory investigators were blinded to the clinical data. A Pearson correlation coefficient was calculated from logarithmically transformed cytokine expression signals using SPSS 16 (SPSS Inc., Chicago, IL).

\section{Immunohistochemical Analyses}

The primary antibodies used are listed Table 2. Affinity purified IL-33Nter rabbit antibody was raised against the first 15 amino acids of human IL-33. Sections $(3 \mu \mathrm{m})$ of formalin-fixed paraffin-embedded samples were deparaffinized before antigen retrieval (Tris-EDTA pH 9.0 buffer for 3 minutes at $750 \mathrm{~W}$ and 20 minutes at $90 \mathrm{~W}$ (Whirlpool Talent Microwave Oven) or for 20 minutes at $100^{\circ} \mathrm{C}$ in a water bath). For enzyme immunohistochemistry, the antibodies were diluted in Ventana Antibody Diluent (Ventana Medical Systems, Tucson, AZ, Cat no. 251-018). Primary antibodies were incubated on the slides for 30 minutes at $37^{\circ} \mathrm{C}$. Detection on human tissue was performed using Ventana ultraView DAB (Cat no. 760-500) or Ventana ultraView Red (Cat. No. 760-501) detection kits according to instructions by the manufacturers (Ventana, Tucson, AZ). Detection on rat tissue was performed using Ventana iView DAB Detection Kit (760-091) or Ventana Enhanced V-Red Detection Kit (760-031) replacing the secondary antibody of the kits with biotinylated rabbit anti-mouse Ig (Dako E0464) or using horseradish peroxidase- or alkaline phosphatase-conjugated Mouse-onRat Polymer Kits (MRT511 and MRT515, Biocare Medi- 
cal, Concord, CA). The slides were washed in Ventana APK detergent (Cat no. 250-042) between incubations. Detailed protocols are available on request. For immunofluorescent detection, primary antibodies were incubated over night $\left(4^{\circ} \mathrm{C}\right)$, followed by secondary antibodies for 2 hours at room temperature and then stained with Hoechst nuclear counterstain for 5 minutes before mounting in polyvinyl alcohol mounting medium, as described elsewhere. ${ }^{16}$ Images were either generated from a Nikon Ellipse E800 microscope equipped with Nikon Plan-Fluor objectives and an F-VIEW digital camera controlled by AnalySIS 3.2 software (Soft Imaging System), or with an Olympus BX51 microscope with an Olympus U-TVO.5XC camera and Olympus CellR image acquisition software.

Cell numbers were related to ulcers or fissures by means of an ocular graticule calibrated to area in specimens and counted by two independent observers (J.S. and $\mathrm{C} . \mathrm{H}$.), yielding an intraclass correlation coefficient of 0.90, calculated in SPSS 16.

\section{Fibroblast Culture}

Human foreskin fibroblasts (NHDF-c, PromoCell, Heidelberg, Germany) were cultured in Fibroblast Growth Medium (C-23010, PromoCell) with SupplementMix (C-39315, PromoCell) containing insulin $(5 \mu \mathrm{g} / \mathrm{ml})$ and basic fibroblast growth factor $(1 \mu \mathrm{g} / \mathrm{ml})$ according to instructions of the vendor. Cells were seeded in gelatin-coated Lab-Tek chamber slides (Nalge Nunc International, Hereford, UK) and stimulated with recombinant human (rh) IL-1 $\beta$, rhIL17, rh-interferon (IFN) $\gamma$, rh-thymic stromal lymphopoietin (TSLP), rhTNF $\alpha$, rh-vascular endothelial growth factor (VEGF)-165, or human platelet-derived, acidactivated, transforming growth factor (TGF)- $\beta 1$ (all from R\&D Systems, Minneapolis, MN). A panel of TLR ligands was obtained from InvivoGen (San Diego, CA). Anti-TLR3 (clone TLR3.7) was from eBiosciences (San Diego, CA). Cells were stained for immunofluorescent analysis with rabbit polyclonal anti-IL-33 (IL-33Nter) and Hoechst nuclear dye as counterstain.

\section{Western Blot Analysis}

Total protein was harvested from fibroblast cultures by lysing them in $2 \times$ Laemmli buffer (4\% SDS, $20 \%$ glycerol, 10\% 2-mercaptoethanol, $0.004 \%$ bromophenol blue, $0.125 \mathrm{~mol} / \mathrm{L}$ Tris-HCl) protease inhibitor cocktail (P-8340, 1:100, Sigma-Aldrich), diluting the lysates 1:1 in PBS and subsequently boiling them for 10 minutes. Protein concentrations were determined using the RC/DC Protein Assay kit (BioRad, Oslo, Norway) and up to $20 \mu \mathrm{g}$ protein was loaded per lane. For visualization of protein loading, membranes were stained with Ponceau $\mathrm{S}$ solution $(0.1 \%$ [w/v] Ponceau S, 5\% acetic acid in $\mathrm{dd}_{2} \mathrm{O}$ ). The protein was blotted to a nitrocellulose membrane (Hybond-ECL, RPN303D, Amersham Biosciences). After blocking in PBS Tween $0.05 \%$ and $5 \%$ milk, IL-33 protein was detected by sequential incubation of blots with mouse antihuman IL-33 (Nessy-1, $1 \mu \mathrm{g} / \mathrm{ml}$ ), biotinylated horse anti- mouse IgG (BA-2000, $3 \mu \mathrm{g} / \mathrm{ml}$, Vector Laboratories), and horseradish peroxidase-conjugated streptavidin (21124, $0.04 \mu \mathrm{g} / \mathrm{ml}$, Pierce, Cramlington, UK). After IL-33 detection, the blots were re-incubated with mouse anti-human actin (sc-8432, 1:500, Santa Cruz, Heidelberg, Germany) followed by the same detection method. Horseradish peroxidase signal was detected by enhanced chemiluminescence substrate (Pierce \#32106) and analyzed on a Kodak Image Station 4000R.

\section{Wound Healing Experiments}

Inbred BD-IX rats were from Charles River Laboratories (Lyon, France) and handled according to national legislation and institutional guidelines. A combination of fentanyl/fluanisone (Hypnorm, Janssen) and midazolam (Dormicum, Roche) was used subcutanously for anesthesia. Bupivacaine (Marcain, AstraZeneca) was applied directly into the wound for additional local analgesia before suturing. The wound healing assay was performed by making a full-thickness, 10-mm, midline skin incision with scissors on the back of the neck and closed with two sutures (Vicryl, 3-0, Ethicon). A boat-shaped $10 \times 5 \mathrm{~mm}$ full-thickness piece of the wounded skin was then harvested using scissors before resuturing.

\section{Results}

\section{Levels of IL-33 mRNA in Colonic UC Biopsies Are Elevated}

The mRNA expression level of IL-33 was analyzed by means of quantitative PCR on colonic biopsies from untreated UC patients $(n=25)$ and controls $(n=22)$. Patients were assigned to four Ulcerative Colitis Disease Activity Index subgroups and the transcript levels compared to those found in control biopsies (Figure 1A), showing that the median mRNA transcript level of IL-33 was 2.6-fold higher in the two subgroups of highest activity compared to controls. In addition, we observed a small number of patients in these subgroups who ex-
A

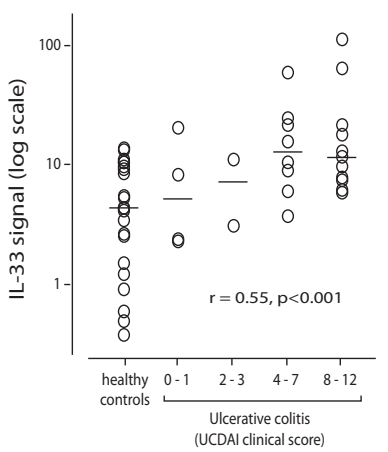

B

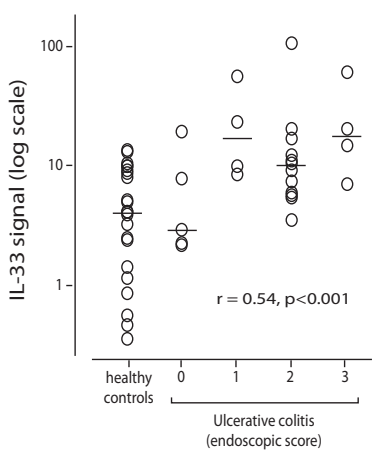

Figure 1. IL-33 mRNA up-regulation in UC correlates with clinical and endoscopic score. Quantitative PCR of IL-33 in biopsies from 25 patients with UC compared to 22 healthy controls showed a moderate but highly significant correlation between IL-33 signal and Ulcerative Colitis Disease Activity Index category (A) and between IL-33 and endoscopic score (B). 
pressed up to 26-fold higher levels of IL-33 mRNA than the median of the control group. Moreover, analysis of log-transformed signal values showed a moderate correlation between relative mRNA IL-33 expression and increasing Ulcerative Colitis Disease Activity Index category $(r=0.55, P<0.001$, Figure $1 \mathrm{~A})$ and between IL-33 expression and increasing endoscopic grade of inflammation $(r=0.54, P<0.001$, Figure $1 \mathrm{~B})$.

\section{IBD-Associated IL-33-Positive Cells Accumulate in UC-Associated Ulcers but Not in CD Fissures}

To explore the cellular sources of enhanced IL-33 expression levels in $U C$ and compare them to $C D$ lesions, we next immunostained resection samples from 6 UC patients, $10 \mathrm{CD}$ patients, and 6 controls (Table 1). The patient samples contained areas ranging from mild chronic to severe chronic active inflammation. Immunostainings were performed with three different antibodies to IL-33 (see Table 2). All antibodies generated similar results but the monoclonal reagent performed with a better signal-to-noise ratio and all immunohistochemical data shown are generated with the monoclonal antibody. We first confirmed our recent findings ${ }^{16}$ and those of others, ${ }^{17}$ that endothelial cells of most blood vessels in the histologically healthy colon are the main IL-33-expressing cell population (Figure 2A) and that the vascular expression levels of IL-33 were generally similar in the IBD lesions (Figure 2B). In addition, we observed that the most superficial blood vessels in the normal colonic lamina propria facing the intestinal lumen expressed only weak or no nuclear IL-33 (Figure 2C). Moreover, we observed an increased density of such IL-33-negative vessels in IBD samples (Figure 2D), perhaps reflecting angiogenic activity. ${ }^{16}$
Interestingly, nuclear expression in enterocytes was not observed in the control samples and was seen only rarely in single crypts of diseased intestine (Figure 2B, but compare to other panels in Figures 2, 3, and 4), therefore contrasting the reported, generalized expression of IL-33 in IBD epithelia. ${ }^{40,41}$ In addition, we observed occasional IL-33 expression in single, nonendothelial cells of the lamina propria, some of which appearing to be pericryptal myofibroblasts based on shape and position (Figure $2 A$, inserts).

Taken together, these findings appeared unsuitable to explain the enhanced level of IL-33-encoding mRNA in UC samples. However, smooth muscle cells of the muscularis mucosae showed a moderate to weak nuclear staining for IL-33 in three out of the six UC samples (Figure 2E). This induction was not observed in control samples (Figure 2F) and seen in only one out of ten $C D$ samples. In addition, careful examination of the rather large surgical specimens revealed that another striking feature of UC samples was the focal accumulation of cells with large, strongly IL-33-positive nuclei underlying ulcerations (Figure 3A). These cells showed a shield-like distribution, restricted to areas where the mucosa was denuded and some cells also showed a cytoplasmic signal compatible with secretion of IL-33 (insert Figure $3 A)$. Accumulations of IL-33 positive cells were seen in all ulcerations larger than $2 \mathrm{~mm}$ in four out of the six UC samples, but were less prominent in smaller ulcers (Figure 3B). Moreover, fissures seen in CD specimens were consistently devoid of such accumulations (Figure 3, B and $\mathrm{C}$ ) and although aggregates of these large, IL-33 cells were also seen in two out of $10 \mathrm{CD}$ samples, they were again observed in ulcer-like lesions (Figure 3B). Thus, given that their distribution appeared so strongly associated with the ulcerations, we analyzed a gastric
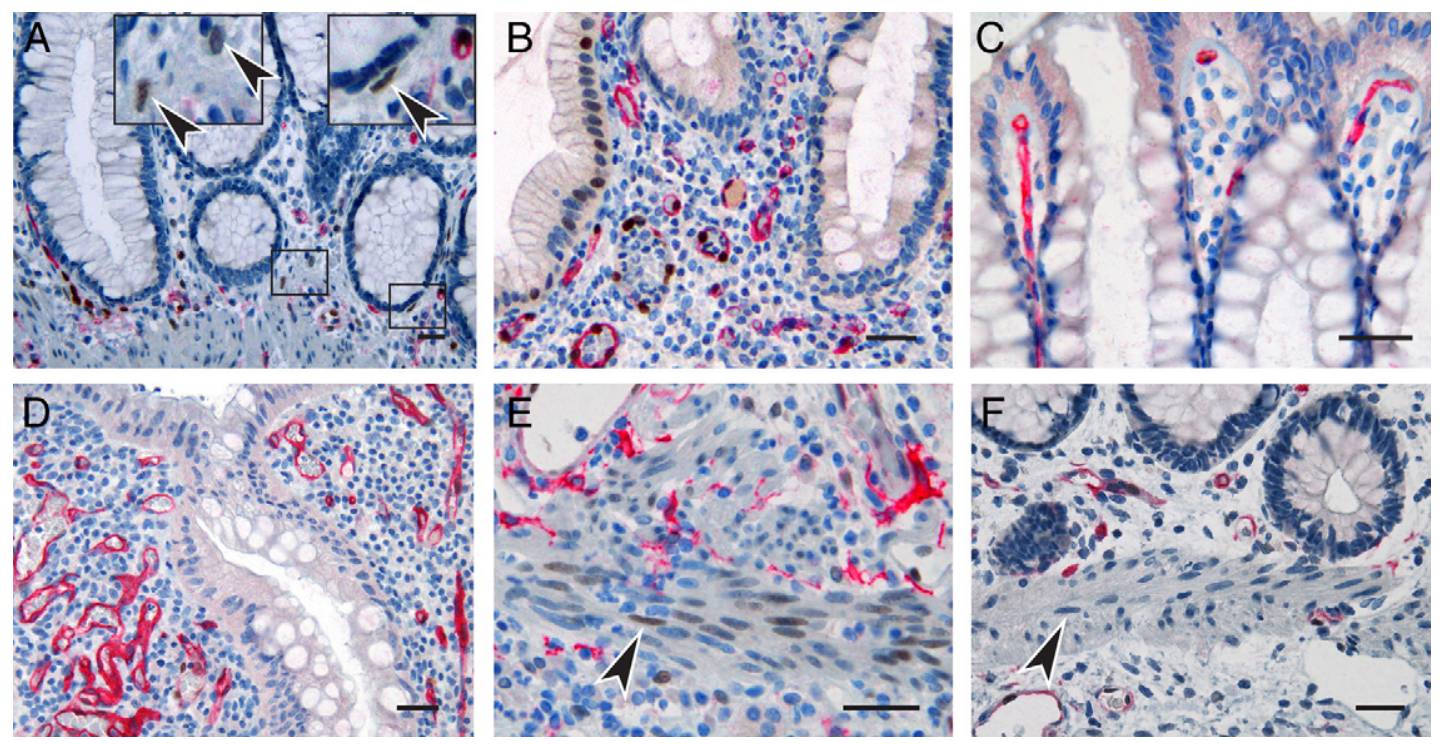

Figure 2. IL-33 expression in endothelial, epithelial, and smooth muscle cells in healthy and inflamed intestine. Immunohistochemical staining of normal colonic mucosa $(\mathbf{A}, \mathbf{C}$, and $\mathbf{F})$, as well as CD $(\mathbf{B})$ and UC (D and $\mathbf{E})$ lesions. Note that endothelial cells of most blood vessels expressed IL-33 in both normal intestine (A) and IBD lesions (B), although IL-33-negative vessels were also seen in luminal areas of healthy intestine (C) and focally in IBD samples (D). Moreover, left inset in panel A shows higher magnification of area with single non-endothelial cells expressing IL-33 and right inset in panel A shows IL-33-expressing, putative pericryptal myofibroblast. Panels $\mathbf{E}$ and $\mathbf{F}$ show focal induction of IL-33 in smooth muscle cell nuclei (arrowheads) of UC lesions (E) but not normal mucosa (F). All panels show IL-33 in brown and CD34 in red. Scale bars $=50 \mu \mathrm{m}$. 


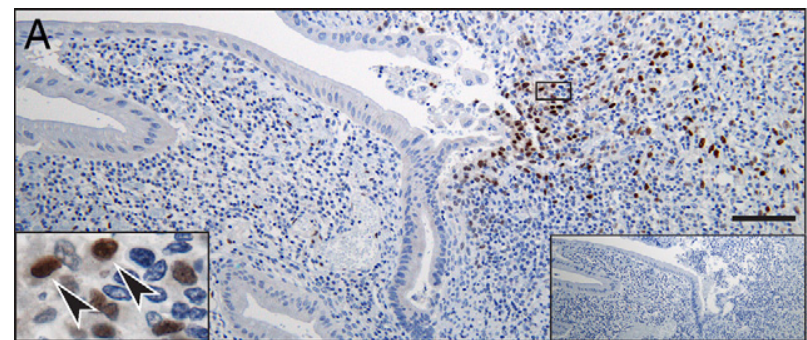

B
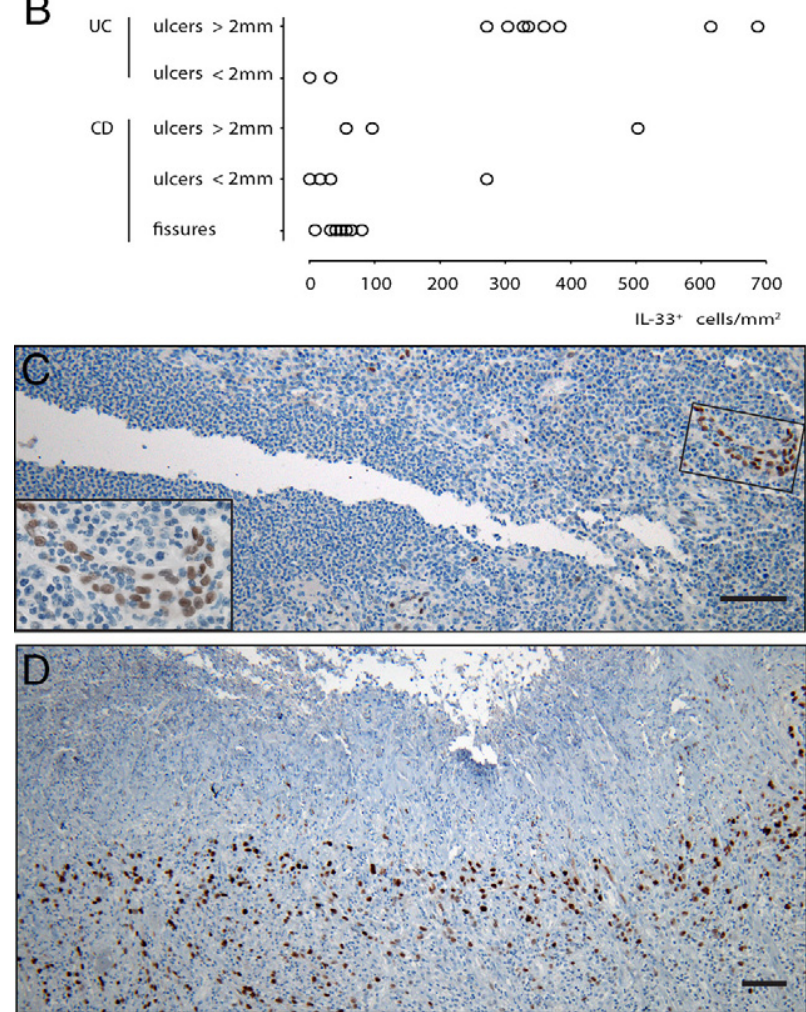

Figure 3. IL-33-positive cells accumulate in UC-associated ulcers but not in CD fissures. Immunohistochemistry of UC (A), CD (C), and gastric mucosae (D) lesions and counts of IL-33-positive cells in IBD lesions (B). Panels $\mathbf{A}$, $\mathbf{C}$, and $\mathbf{D}$ show IL-33 in brown. Left inset in panel $\mathbf{A}$ shows higher magnification of area with solid frame in the main panel, arrowheads point to cells with cytoplasmic in addition to nuclear signal. Right inset in panel $\mathbf{A}$ shows subclass- and concentration-matched negative control in serial section. Inset in panel $\mathbf{C}$ shows IL-33-positive venule at higher magnification framed in the main panel. Scale bars $=200 \mu \mathrm{m}$.

ulcer, again finding abundant amounts of similar cells located luminally in the granulation tissue (Figure 3D).

\section{Up-Regulation of IL-33 in UC Lesions May Predominantly Originate from Ulcer Infiltration by Fibroblasts/Myofibroblasts}

In efforts to identify the ulceration-associated, IL-33-positive cells, we first assessed if they might be single, angiogenic endothelial cells. However, the lack of costaining for cluster differentiation antigen (CD)34, CD31, or VE-cadherin (Figure 4, A-C) did not support this hypothesis. Given the large size of their nuclei, we then speculated if they might be macrophages or mast cells, but they failed to co-stain for CD68 or mast cell tryptase, as well as the hematopoietic cell marker CD45 (Figure 4, $D-F)$, rather pointing to a stromal cell origin. Accordingly, virtually all IL-33-positive cells expressed vimentin, and a large fraction were $\alpha$-smooth muscle actin $(\alpha \mathrm{SMA})$ positive (Figure 4, $\mathrm{G}$ and $\mathrm{H}$ ). The expression of $\alpha \mathrm{SMA}$ narrowed our focus to myoepithelial cells, smooth muscle cells, pericytes, or myofibroblasts. To this end, the lack of costaining for pancytokeratin or desmin (Figure 4, I and $\mathrm{J}$ ) as well as their stellate morphology (insert Figure $4 \mathrm{H}$ ) led to the conclusion that $\alpha$ SMA-positive myofibroblasts were a prominent population among the ulceration-associated IL-33-positive cells. Accordingly, we hypothesized that the population of $\alpha$ SMA-negative cells in this area may be activated fibroblasts/ $\alpha$ SMA-negative myofibroblasts that had not yet differentiated to express $\alpha \mathrm{SMA}$. This hypothesis was supported by the observation that all of the IL-33-positive cells appeared to express heat shock protein 47 (Figure 4K), a chaperone for collagens that has been associated with fibroblasts in wound healing, ${ }^{42}$ as well as platelet-derived growth factor receptor $\beta$ (PDGFR $\beta$ ), essential for fibroblast and pericyte recruitment during wound healing (Figure $4 \mathrm{~L}$ ). ${ }^{43}$

\section{The TLR3 Agonist Poly (l:C) and TGF $\beta$ Synergize to Induce IL-33 in Fibroblasts}

To map possible inducers of IL-33 in fibroblasts and myofibroblasts, we next analyzed the expression of IL-33 in human fibroblast cultures. We confirmed that IL-33 can be induced in fibroblasts upon activation with TNF $\alpha$ and/or IL- $1 \beta^{9,10}$ peaking at 12 hours (Figure 5, A and B). On the other hand, testing Th1-associated IFN- $\gamma$, we observed only weak induction at $100 \mathrm{ng} / \mathrm{ml}$ (Table 3). Moreover, Th17-associated IL-17 and Th2-associated IL-4 and IL-13 gave no response (Table 3). However, under the assumption that inflamed gut lesions generally contain elevated levels of these cytokines, it appeared that they might not be sufficient to drive in vivo expression of nuclear IL-33 in fibroblasts that are not associated with the base of ulcers. We therefore tested the effect of TGF $\beta$, thymic stromal lymphopoietin, (TSLP) or VEGF, all known to be released from damaged epithelial barriers, observing that they also gave no response to the expression level of nuclear IL-33 (Figure 5D and Table 3). We then considered the possibility that an increased exposure to components of the gut flora could be involved in IL-33 induction and assessed the effect of ligands to TLRs known to be expressed in fibroblasts (TLR2, -3 , -4 , and -9 ), observing that the TLR4 ligand lipopolysaccharide and in particular the TLR3 ligand poly (I:C) induced IL-33, the latter to a level higher than that observed when exposing the cells to IL-1 $\beta$ or TNF $\alpha$ alone and similar to that seen in response to the combination of both cytokines (Figure 5A and Table 3) but in contrast to the cytokine response reaching maximum expression levels at 24 hours (Figure 5B). The TLR2 ligands heatkilled Listeria Monocytogenes (HKLM) or lipoteichoic acid, as well as the TLR9 ligand ODN2006 showed no 

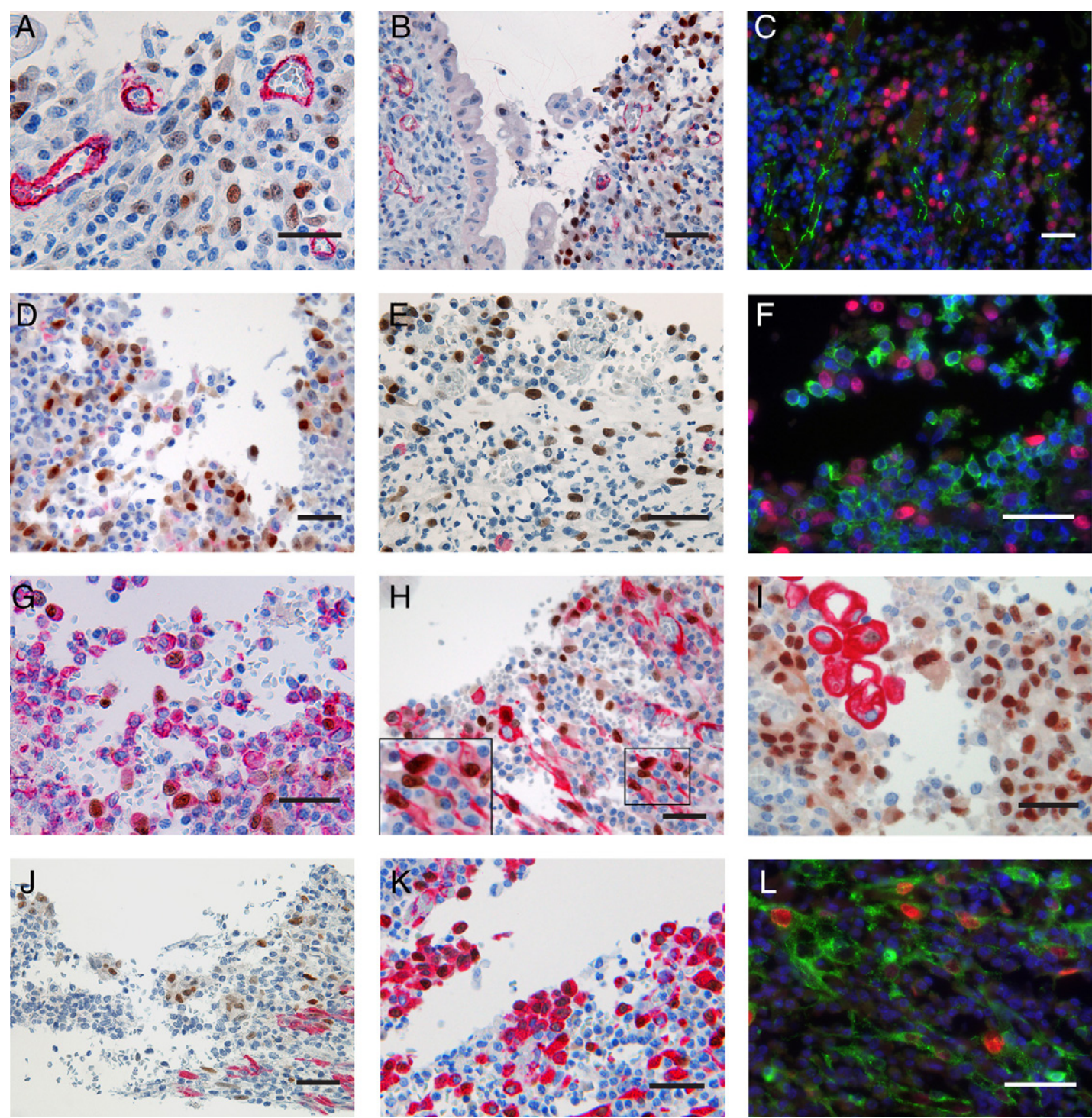

Figure 4. Identification of ulcer-associated IL-33-positive cells in UC. Immunohistochemistry (A, B, D, and $\mathbf{E}$, and $\mathbf{G}-\mathbf{K})$ and immunofluorescence $(\mathbf{C}, \mathbf{F}$, and $\mathbf{L})$ of UC ulcers. Panels $\mathbf{A}, \mathbf{B}, \mathbf{D}$ and $\mathbf{E}$, and $\mathbf{G}-\mathbf{K}$ show IL-33 in brown and CD34 (A), CD31 (B), CD68 (D), mast cell tryptase $(\mathbf{E})$, vimentin $(\mathbf{G}), \alpha$ SMA $(\mathbf{H})$, pancytokeratin $(\mathbf{I})$, desmin $(\mathbf{J})$, or heat shock protein $47(\mathbf{K})$ in red. Panels $\mathbf{C}, \mathbf{F}$, and $\mathbf{L}$ show IL-33 in red and VE-cadherin $(\mathbf{C}), \mathrm{CD} 45$ (clone 135-4C5) (F), or PDGFR $\beta(\mathbf{L})$ in green and cell nuclei in blue. Left inset in panel $\mathbf{H}$ shows higher magnification of area with solid frame in the main panel. Scale bars $=50 \mu \mathrm{m}$.

induction over background levels. All stimulation data are summarized in Table 3.

Given the roles of newly discovered pathways for detecting double-stranded RNA (RIG-I and MDA-5) ${ }^{44}$ in addition to TLR3 ligation, we asked whether the effect of poly (I:C) was mediated via TLR3. Addition of a blocking antibody to TLR3 ${ }^{45}$ led to a reduction in IL-33 expression (Figure 5C). We then asked whether the IL-33-inducing effect of poly (I:C) might be potentiated by the addition of TGF $\beta$, given the recent demonstration that TLR3 activation augments production of collagen and fibronectin in myofibroblast via TGF $\beta{ }^{46}$ Indeed, while addition of TGF $\beta$ alone had no effect on IL-33 expression and the effect of poly (I:C) was moderate, we found TGF $\beta$ to synergistically boost the effect of poly (I:C)-induced expression of IL-33 (Figure 5, D and E).

\section{IL-33-Expressing Myofibroblasts in Wound Healing May Be Generated from Pericytes}

To assess if the recruitment of IL-33-positive fibroblasts and myofibroblasts to the granulation tissue of mucosal ulcers could be generalized to also include wound healing in other organs and to shed light on the origin of these cells, we analyzed samples collected from healing skin wounds in the rat. In control samples (Figure 6A) we found IL-33 in endothelial cell nuclei, as published elsewhere, ${ }^{16}$ and, at a generally lower expression level, in rare, scattered cells with chromatin-dense cigar-shaped nuclei compatible with being fibroblasts (Figure 6C, arrowheads, upper panel). By contrast, in the granulation tissue of healing wounds (Figure 6B) we observed a massive recruitment of cells that showed a strong nuclear 
A
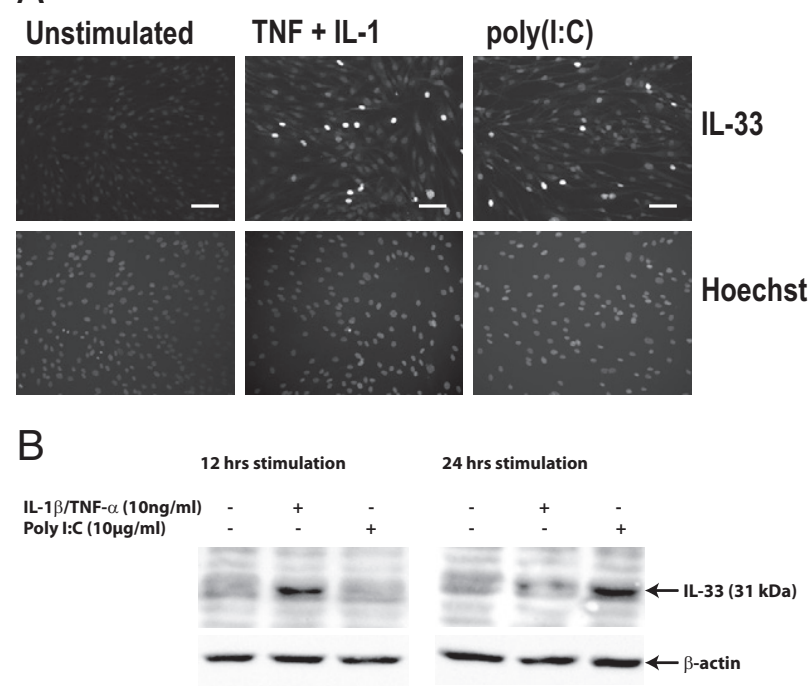

C

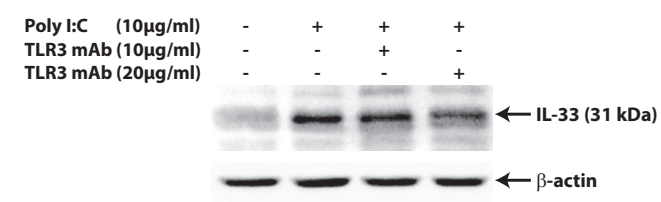

$\mathrm{D}$
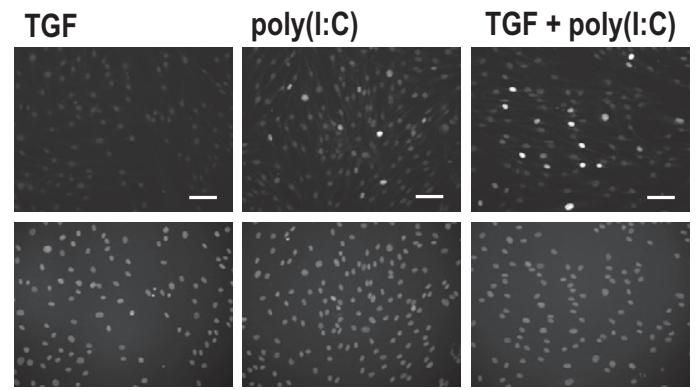

IL-33
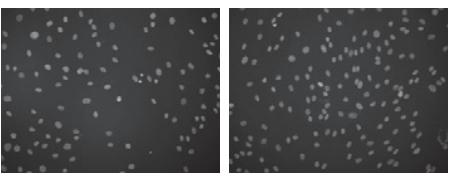

E

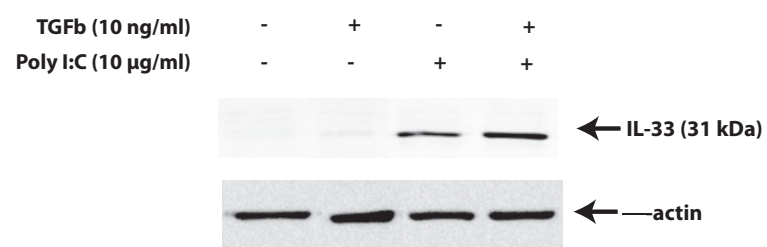

Figure 5. Pro-inflammatory regulation of nuclear IL-33 in fibroblasts. A: Immunocytochemistry of dermal fibroblasts expressing IL-33 in the absence or presence of TNF $\alpha$ and IL- $1 \beta$ ( $10 \mathrm{ng} / \mathrm{ml}$ and $10 \mathrm{ng} / \mathrm{ml}$ for 12 hours) or poly (I:C) $(10 \mu \mathrm{g} / \mathrm{ml}$ for 24 hours $)$. B: Western blot of dermal fibroblast lysates; time course of IL-33 expression in response to TNF $\alpha / \mathrm{IL}-1 \beta$ or poly (I:C), reagent concentrations as in $\mathbf{A}$. C: Western blot of dermal fibroblast lysates; monoclonal antibody to TLR3 (clone TLR3.7, 10 , or $20 \mu \mathrm{g} / \mathrm{ml}$ ) was added to cultures 60 minutes before the addition of poly (I:C) and found to inhibit expression of IL-33. D and E: Synergistic effect of poly (I:C) $(10 \mu \mathrm{g} / \mathrm{ml})$ and TGF $\beta(10 \mathrm{ng} / \mathrm{ml})$ on expression of IL-33 shown by immunocytochemistry (D) and Western blot (E) of dermal fibroblasts.

signal for IL-33. Moreover, by analyzing a time course of biopsy specimens, we observed that nuclear IL-33 was induced in $\alpha \mathrm{SMA}$-positive pericytes (Figure 6C, arrows) as soon as 24 hours after wounding but also the occur-
Table 3. Summary of IL-33 Induction in Fibroblasts Exposed to Cytokines, Growth Factors, or TLR Ligands

\begin{tabular}{lccc}
\hline IL-1 $\beta(10 \mathrm{ng} / \mathrm{ml})^{*}$ & $++{ }^{* *}$ & & \\
TNF $\alpha(10 \mathrm{ng} / \mathrm{ml})$ & ++ & IL-1 $\beta /$ TNF $\alpha$ & +++ \\
LPS $(10 \mu \mathrm{g} / \mathrm{ml})$ & + & TNF $\alpha / \mathrm{LPS}$ & ++ \\
HKLM $\left(10^{8} \mathrm{cells} / \mathrm{ml}\right)$ & - & & \\
LTA $(100 \mu \mathrm{g} / \mathrm{ml})$ & - & \\
ODN $2006(10 \mu \mathrm{mol} / \mathrm{L})$ & - & \\
poly $(\mathrm{l}: \mathrm{C})(10 \mu \mathrm{g} / \mathrm{ml})$ & $++(+)$ & \\
TGF $\beta(10 \mathrm{ng} / \mathrm{ml})$ & - & poly $(\mathrm{I}: \mathrm{C}) / \mathrm{TGF} \beta$ & ++++ \\
VEGF $(100 \mathrm{ng} / \mathrm{ml})$ & - & \\
PDGF $(100 \mathrm{ng} / \mathrm{ml})$ & - & \\
IL-4 $(100 \mathrm{ng} / \mathrm{ml})$ & - & \\
IL-13 $(100 \mathrm{ng} / \mathrm{ml})$ & - & \\
IL-17 $(100 \mathrm{ng} / \mathrm{ml})$ & - & \\
IFN $\gamma(100 \mathrm{ng} / \mathrm{ml})$ & + & \\
TSLP(100 $\mathrm{ng} / \mathrm{ml})$ & - & \\
\hline
\end{tabular}

*Upper concentration of agonists tested in a range of three log levels in three independent experiments.

${ }^{*}$ Expression levels were assessed by microscopic evaluation of immunostained cells or band intensity of Western blots on a scale from - to ++++ .

rence of a strong nuclear IL-33 signal in $\alpha$ SMA-negative cells with large, round nuclei that were not in direct contact with the vessels (Figure 6C, arrowheads). To further dissect the phenotypes of IL-33-expressing cells, we co-stained for PDGFR $\beta$, another pericyte-associated marker thought to be involved in endothelial cell-pericyte interaction. ${ }^{47}$ However, we observed that PDGFR $\beta$ was detectable not only on pericytes, but also to a lesser extent on the cigar-shaped IL-33-positive cells seen in control samples (Figure 6C). In the course of the following days, PDGFR $\beta$ expression appeared to increase on IL33-positive cells, peaking at day 6. In addition, we observed co-expression of $\alpha$ SMA at day 4 , also peaking at day 6 (Figure 6C).

\section{Discussion}

The discovery of IL-33 and its association to Th2 immunity has raised the question of how it behaves in chronic inflammatory lesions. In this study, we observed that a dominant source of elevated mRNA IL-33 levels in UC lesions may be myofibroblasts in the granulation tissue of ulcers. This observation prompted us to also look in gastric ulceration and experimental wound healing of the skin, allowing us to conclude that the accumulation of IL-33-positive myofibroblasts may be a general feature of mucosal healing and wound repair.

The development of myofibroblasts from connective tissue fibroblasts in wound repair is a process driven by TGF $\beta$ and mechanical strain, ${ }^{48}$ in which the fibroblast acquires the $\alpha$ SMA-containing stress fibers thought necessary to achieve the contraction of the wound and successful healing. ${ }^{49}$ Our observation that TGF $\beta$ also acts to boost the TLR3-driven induction of IL-33 in cultured fibroblasts is intriguing because it appears to be well in line with the recent observation that TLR3 activation also drives myofibroblast differentiation. ${ }^{46}$ While TLR3 is commonly thought to signal the presence of virus-derived double stranded RNA, it can also be activated by host 

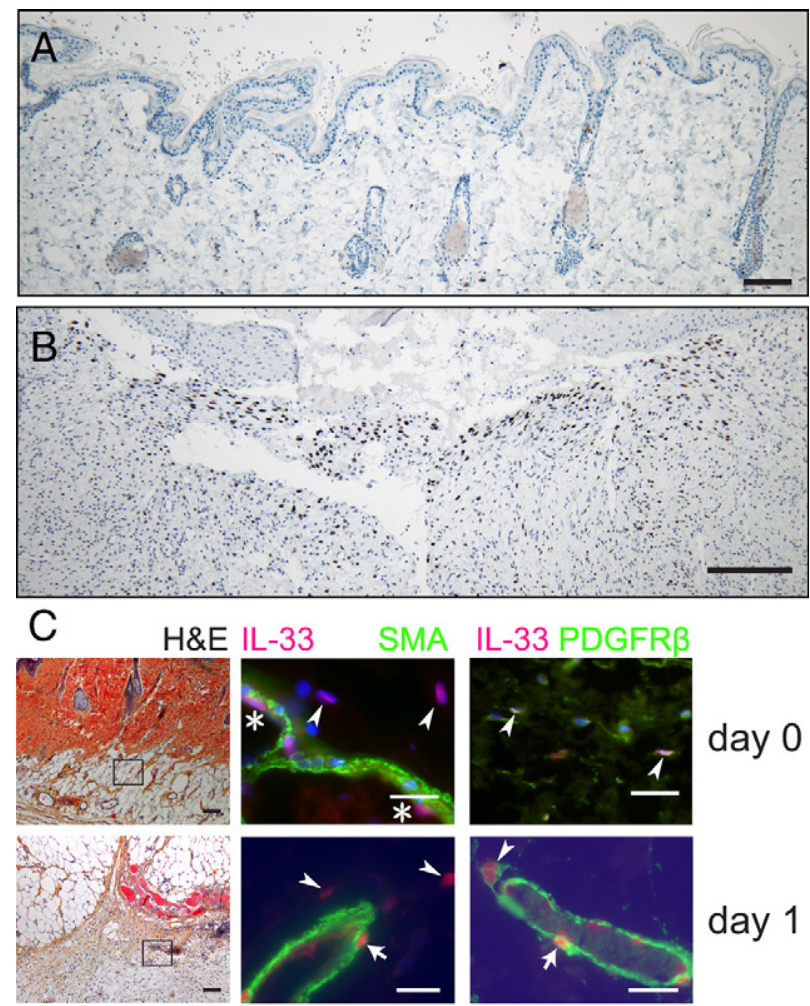

day 0
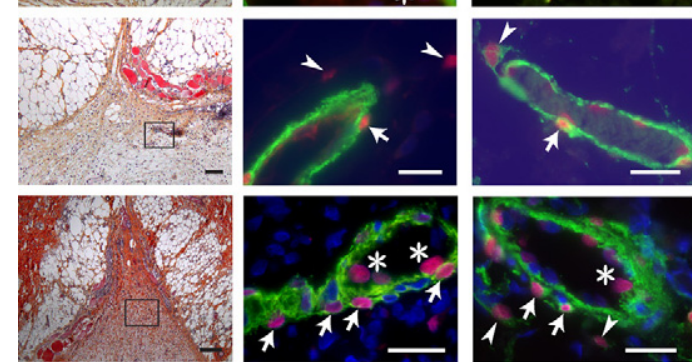

day 2
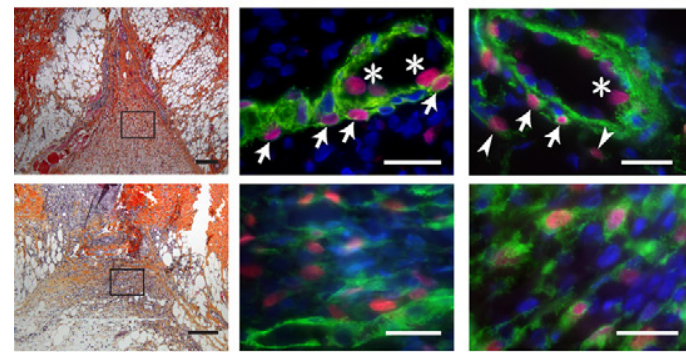

day 4
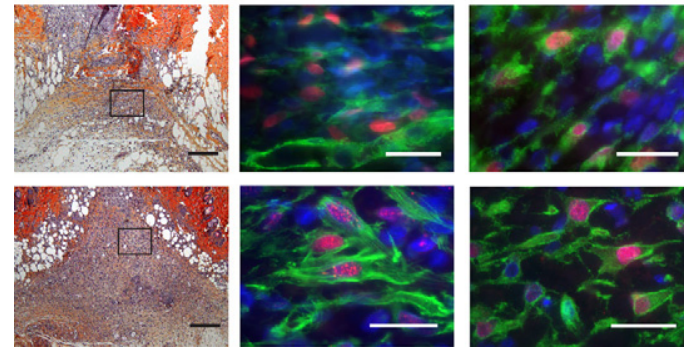

Figure 6. IL-33-positive fibroblasts and myofibroblasts accumulate in dermal wound repair. Immunohistochemistry of healthy skin (A) and healing, incisional wound at day 9 (B), showing IL-33 signal in brown. Panel $\mathbf{C}$ shows healthy control skin and wounds harvested at days 1,2, 4, and 6 with H\&E-stained overviews in the left column, IL-33 (red) and $\alpha$ SMA (green) in the middle column and IL-33 (red) and PDGFR $\beta$ (green) in the right column. Areas of immunofluorescent detection are outlined in the H\&E images. Arrowheads point to single IL-33-positive cells and arrows to IL-33-positive pericytes. Some endothelial cell nuclei as labeled with an asterisk for clarity. Scale bars: panels $\mathbf{A}$ and $\mathbf{B}$ and left panel in $\mathbf{C}(200 \mu \mathrm{m})$; and middle and right panels in $\mathbf{C}(50 \mu \mathrm{m})$.

mRNA released from damaged or necrotic cells, a scenario compatible with loss of the epithelial barrier. ${ }^{33}$ Thus, if the recruitment of IL-33-positive fibroblasts to ulcers is a protective process (based on its similarity to the physiological wound healing seen in the skin), it is tempting to consider that such mechanisms may contribute to explaining why TLR3 activation protects against dextran sulphate sodium-induced colitis. ${ }^{50}$ Conversely, the lack of IL-33-positive myofibroblast accumulations near the deep fissures of CD-lesions may reflect a reduced response of fibroblasts to breaks in the epithelial barrier in
CD. To this end, it is interesting to note that TLR3 expression is reportedly reduced in $C D^{51}$ and $T L R 3$, localized on chromosome 4 (q35), is bordering a linkage region of an IBD susceptibility gene. ${ }^{52}$ The inhibition of poly (I:C)-induced IL-33 expression by means of a monoclonal antibody to TLR3 implies that at least part of the effect is mediated via this receptor. Of note, this antibody inhibited only about $50 \%$ of the IFN $\beta$ production in lung-derived fibroblasts, ${ }^{45}$ pointing either to an incomplete blocking effect or the presence of for example RIG-I-like receptors, ${ }^{44}$ that also sense RNA and so could explain the remaining response to poly (I:C). It will therefore be interesting to further dissect the mechanisms underlying the response of IL-33 to poly (I:C).

It appears equally interesting that while lamina propria mononuclear cells from UC patients showed increased production of TGF $\beta$ compared to controls, lower levels were observed in $C D$ samples, ${ }^{53}$ perhaps reflecting a suppressive role of CD-associated IFN- $\gamma$ on the production of TGF $\beta$. In addition, IFN- $\gamma$ inhibits TGF $\beta$ signaling ${ }^{54}$ and $\alpha$ SMA induction in fibroblasts, ${ }^{55}$ perhaps explaining the inhibitory role of IFN- $\gamma$ in wound healing. ${ }^{56}$ Moreover, IFN- $\gamma$ in combination with TNF $\alpha$ has been associated with the apparent loss of pericryptal intestinal myofibroblasts ${ }^{57}$ and reduced migration of intestinal fibroblasts. ${ }^{58}$

It is thought that myofibroblasts can develop from tissue-resident fibroblasts and to this end we observed nuclear IL-33 expression in fibroblast-like cells in intact skin and healthy colon. Moreover, it was interesting to observe in the wound model that nuclear IL-33 was also induced in pericytes. These pericytes were PDGFR $\beta$ positive and although not formally proven in our study, their phenotypic change and positioning appear well in

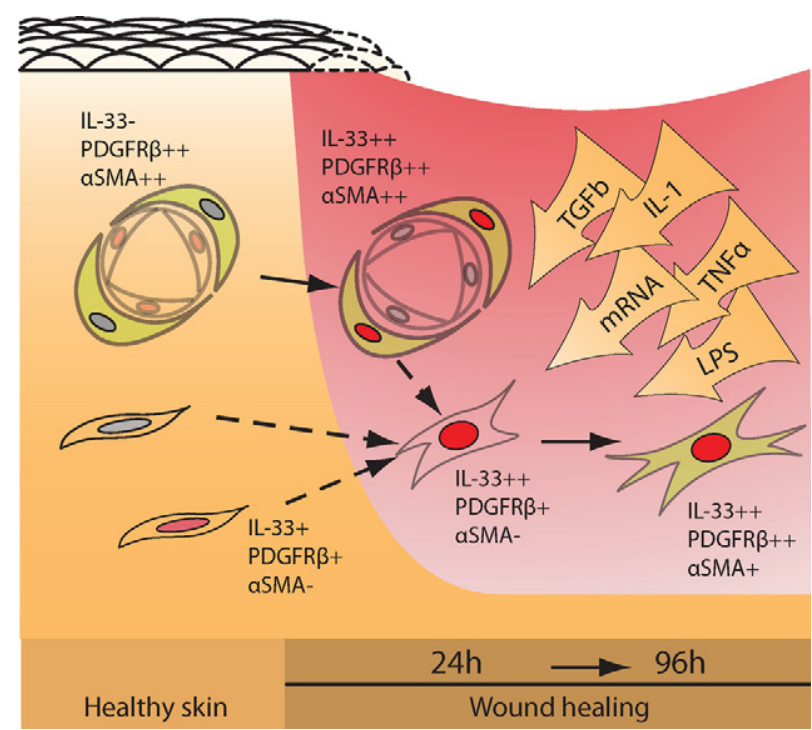

Figure 7. Schematic representation of IL-33-induction in fibroblasts, pericytes, and myofibroblasts during wound healing. Stromal, tissue-resident fibroblasts (IL-33-positive or - negative) are activated by mRNA/TGF $\beta$ / lipopolysaccharide to express nuclear IL-33 (red nuclei) and may contribute to the pool of myofibroblasts invading the wound area. Likewise, pericytes become activated and may contribute to this pool. By contrast, vascular endothelial cells, which are strongly positive in healthy tissue, down-regulate IL-33 in the course of activation. ${ }^{16}$ 
line with the recent observation that pericytes are a major source of myofibroblasts in kidney fibrosis, ${ }^{59,60}$ and that blocking PDGFR $\beta$ signaling inhibits myofibroblast recruitment in wound healing. ${ }^{43}$ On the other hand, it is equally possible that the IL-33/PDGFR $\beta$ double-positive, putative fibroblasts of intact rat skin were the origin of the IL-33/ PDGFR $\beta$ double-positive cells with round enlarged nuclei seen after wounding. These possible chains of events are schematically summarized in Figure 7. In addition, we have not ruled out the possibility that smooth muscle cells, endothelial cells, and even epithelial cells transdifferentiating to a mesenchymal phenotype are among the sources of IL-33-positive myofibroblasts in skin wounds.

Although we could not extend our observations of pericyte activation to the ulcerations of UC lesions, IL-33 appears well suited to enhance the resolution of myofibroblast characterization, not only in IBD, but also in fibroblast function of other organs. It is known that fibroblasts and myofibroblasts each show a spectrum of different phenotypes. To this end, our observations appear to establish nuclear IL-33 as an early marker for ulcerassociated activated fibroblasts and myofibroblasts and it may prove useful to link specific functions to specific subtypes of these cells.

The modest increase of IL-33 mRNA levels and association to UC disease activity that we observed in untreated UC patients is generally well in line with two recent reports on the subject. ${ }^{40,41}$ Moreover, protein levels of IL-33 of solubilized samples were similarly increased. ${ }^{41}$ On the other hand, our immunohistochemical analysis of IL-33 is at variance with the reported data because both reports conclude that there is a general IBD-associated signal from epithelial cells, whereas we only observed IL-33 in scattered crypts. These differences may possibly be attributed to different antibodies and/or different protocols, but it also appears likely that our use of surgical specimens that are substantially larger than biopsy specimens ( $20 \mathrm{~mm}$ vs. $2 \mathrm{~mm}$ ), were indeed required to discover the highly focused expression of IL-33 in ulcerations.

The observation that IL-33 is associated with areas of broken barrier function also prompts a discussion of mucosal healing. Increased permeability and diarrhea are the virtually ever present symptoms in active IBD. In this situation, the epithelial barrier is dysfunctional, either disrupted in active IBD lesions, or as in chronic IBD showing signs of persistent mucosal leakiness ${ }^{61,62}$ Accordingly, the concept of mucosal healing is getting increased attention as an optimal treatment goal for IBD patients, because such patients are more likely to stay in long-term remission. ${ }^{63}$ Conversely, the process of regeneration associated with chronic inflammation appears to be closely related to the generation of excess connective tissue and the development of fibrosis. It is therefore of high interest to more fully understand the cellular functions central to these repair processes and to analyze more carefully if the elevated serum levels of IL-33 observed by Beltran et $\mathrm{al}^{41}$ can be correlated to barrier function.

The function of IL-33 in fibroblasts, pericytes, and myofibroblasts is currently unknown. The transcriptional repressor activity of IL-33 in recombinant systems ${ }^{20}$ implies that IL-33 may affect their nuclear functions, but it is also possible that IL-33 is released from these cells. Indeed, we observed scattered cells in ulcers that also showed a signal for IL-33 in their cytoplasm but our efforts to measure IL-33 in the supernatant of cultured fibroblasts were not successful. Nevertheless, secretion of IL-33 may serve to recruit ST2-expressing leukocytes to the ulceration, but it is also possible that IL-33 release may promote angiogenesis, ${ }^{14}$ and perhaps scar formation, ${ }^{30}$ by acting directly or indirectly on stromal cells. It will be interesting to analyze the outcome of both experimental colitis and wound healing in IL-33-deficient animals.

\section{Acknowledgments}

We thank Linda Manley for expert technical assistance, Are H. Pripp for assistance with the statistical analysis, and Helge Scott, Finn-Eirik Johansen, Frode Jahnsen, Per Brandtzaeg, and Harald Torsvik for helpful discussions, and Robert Burns for providing antibodies.

\section{References}

1. Abraham C, Cho JH: Inflammatory bowel disease. N Engl J Med 2009, 361:2066-2078

2. Vermeire S, Van Assche G, Rutgeerts P: Serum sickness, encephalitis and other complications of anti-cytokine therapy. Best Pract Res Clin Gastroenterol 2009, 23:101-112

3. Mackey AC, Green L, Liang LC, Dinndorf P, Avigan M: Hepatosplenic $T$ cell lymphoma associated with infliximab use in young patients treated for inflammatory bowel disease. J Pediatr Gastroenterol Nutr 2007, 44:265-267

4. Shale M, Ghosh S: Beyond TNF. Th1 and Th2 in inflammatory bowel disease. Gut 2008, 57:1349-1351

5. Rutgeerts P, Vermeire S, Van Assche G: Biological therapies for inflammatory bowel diseases. Gastroenterology 2009, 136:11821197

6. Arend WP, Palmer G, Gabay C: IL-1, IL-18, and IL-33 families of cytokines. Immunol Rev 2008, 223:20-38

7. Kakkar R, Lee RT: The IL-33/ST2 pathway: therapeutic target and novel biomarker. Nat Rev Drug Discov 2008, 7:827-840

8. Dinarello CA: Immunological and inflammatory functions of the interleukin-1 family. Annu Rev Immunol 2009, 27:519-550

9. Schmitz J, Owyang A, Oldham E, Song Y, Murphy E, McClanahan TK, Zurawski G, Moshrefi M, Qin J, Li X, Gorman DM, Bazan JF, Kastelein RA: IL-33, an interleukin-1-like cytokine that signals via the IL-1 receptor-related protein ST2 and induces T helper type 2-associated cytokines. Immunity 2005, 23:479-490

10. Xu D, Jiang HR, Kewin P, Li Y, Mu R, Fraser AR, Pitman N, KurowskaStolarska M, McKenzie AN, McInnes IB, Liew FY: IL-33 exacerbates antigen-induced arthritis by activating mast cells. Proc Natl Acad Sci USA 2008, 105:10913-10918

11. Palmer G, Talabot-Ayer D, Lamacchia C, Toy D, Seemayer CA, Viatte S, Finckh A, Smith DE, Gabay C: Inhibition of interleukin-33 signaling attenuates the severity of experimental arthritis. Arthritis Rheum 2009, 60:738-749

12. Liew FY, Pitman NI, Mclnnes IB: Disease-associated functions of IL-33: the new kid in the IL-1 family. Nat Rev Immunol 2010, 10:103-110

13. Murphy GE, Xu D, Liew FY, Mclnnes IB: Role of interleukin 33 in human immunopathology. Ann Rheum Dis 2010, 69 Suppl 1:i43-i47

14. Choi YS, Choi HJ, Min JK, Pyun BJ, Maeng YS, Park H, Kim J, Kim YM, Kwon YG: IL-33 induces angiogenesis and vascular permeability through ST2/TRAF6-mediated endothelial NO production. Blood 2009, 114:3117-3126

15. Nishida A, Andoh A, Imaeda H, Inatomi O, Shiomi H, Fujiyama Y: Expression of interleukin 1-like cytokine interleukin 33 and its receptor 
complex (ST2L and IL1RAcP) in human pancreatic myofibroblasts. Gut 2010, 59:531-541

16. Kuchler AM, Pollheimer J, Balogh J, Sponheim J, Manley L, Sorensen DR, De Angelis PM, Scott H, Haraldsen G: Nuclear interleukin-33 is generally expressed in resting endothelium but rapidly lost upon angiogenic or proinflammatory activation. Am J Pathol 2008, 173:1229-1242

17. Moussion C, Ortega N, Girard JP: The IL-1-like cytokine IL-33 is constitutively expressed in the nucleus of endothelial cells and epithelial cells in vivo: a novel 'alarmin'? PLoS ONE 2008, 3:e3331

18. Onda H, Kasuya H, Takakura K, Hori T, Imaizumi T, Takeuchi T, Inoue I, Takeda J: Identification of genes differentially expressed in canine vasospastic cerebral arteries after subarachnoid hemorrhage. J Cereb Blood Flow Metab 1999, 19:1279-1288

19. Baekkevold ES, Roussigne M, Yamanaka T, Johansen FE, Jahnsen FL, Amalric F, Brandtzaeg P, Erard M, Haraldsen G, Girard JP: Molecular characterization of NF-HEV, a nuclear factor preferentially expressed in human high endothelial venules. Am J Pathol 2003, 163:69-79

20. Carriere V, Roussel L, Ortega N, Lacorre DA, Americh L, Aguilar L, Bouche G, Girard JP: IL-33, the IL-1-like cytokine ligand for ST2 receptor, is a chromatin-associated nuclear factor in vivo. Proc Natl Acad Sci USA 2007, 104:282-287

21. Roussel L, Erard M, Cayrol C, Girard JP: Molecular mimicry between IL-33 and KSHV for attachment to chromatin through the H2A-H2B acidic pocket. EMBO Rep 2008, 9:1006-1012

22. Sanada S, Hakuno D, Higgins LJ, Schreiter ER, McKenzie AN, Lee RT: IL-33 and ST2 comprise a critical biomechanically induced and cardioprotective signaling system. J Clin Invest 2007, 117:1538-1549

23. Hudson CA, Christophi GP, Gruber RC, Wilmore JR, Lawrence DA, Massa PT: Induction of IL-33 expression and activity in central nervous system glia. J Leukoc Biol 2008, 84:631-643

24. Marvie P, Lisbonne M, L'Helgoualc'h A, Rauch M, Turlin B, Preisser L, Bourd-Boittin K, Theret N, Gascan H, Piquet-Pellorce C, Samson M: Interleukin-33 overexpression is associated with liver fibrosis in mice and humans. J Cell Mol Med 2010, 14:1726-1739

25. Li H, Willingham SB, Ting JP, Re F: Cutting edge: inflammasome activation by alum and alum's adjuvant effect are mediated by NLRP3. J Immunol 2008, 181:17-21

26. Talabot-Ayer D, Lamacchia C, Gabay C, Palmer G: Interleukin-33 is biologically active independently of caspase-1 cleavage. J Biol Chem 2009, 284:19420-19426

27. Luthi AU, Cullen SP, McNeela EA, Duriez PJ, Afonina IS, Sheridan C, Brumatti G, Taylor RC, Kersse K, Vandenabeele P, Lavelle EC, Martin SJ: Suppression of interleukin-33 bioactivity through proteolysis by apoptotic caspases. Immunity 2009, 31:84-98

28. Cayrol C, Girard JP: The IL-1-like cytokine IL-33 is inactivated after maturation by caspase-1. Proc Natl Acad Sci USA 2009, 106: 9021-9026

29. Haraldsen G, Balogh J, Pollheimer J, Sponheim J, Kuchler AM: Interleukin-33 - cytokine of dual function or novel alarmin? Trends Immunol 2009, 30:227-233

30. Rankin AL, Mumm JB, Murphy E, Turner S, Yu N, McClanahan TK, Bourne PA, Pierce RH, Kastelein R, Pflanz S: IL-33 induces IL-13dependent cutaneous fibrosis. J Immunol 2009, 184:1526-1535

31. Humphreys NE, Xu D, Hepworth MR, Liew FY, Grencis RK: IL-33, a potent inducer of adaptive immunity to intestinal nematodes. J Immunol 2008, 180:2443-2449

32. Heller F, Florian P, Bojarski C, Richter J, Christ M, Hillenbrand B, Mankertz J, Gitter AH, Burgel N, Fromm M, Zeitz M, Fuss I, Strober W, Schulzke JD: Interleukin-13 is the key effector Th2 cytokine in ulcerative colitis that affects epithelial tight junctions, apoptosis, and cell restitution. Gastroenterology 2005, 129:550-564

33. Kariko K, Ni H, Capodici J, Lamphier M, Weissman D: mRNA is an endogenous ligand for Toll-like receptor 3. J Biol Chem 2004, 279: $12542-12550$

34. Sands BE: From symptom to diagnosis: clinical distinctions among various forms of intestinal inflammation. Gastroenterology 2004, 126:1518-1532

35. Sutherland LR, Martin F, Greer S, Robinson M, Greenberger N, Saibil F, Martin T, Sparr J, Prokipchuk E, Borgen L: 5-Aminosalicylic acid enema in the treatment of distal ulcerative colitis, proctosigmoiditis, and proctitis. Gastroenterology 1987, 92:1894-1898
36. Olsen T, Goll R, Cui G, Husebekk A, Vonen B, Birketvedt GS, Florholmen J: Tissue levels of tumor necrosis factor-alpha correlates with grade of inflammation in untreated ulcerative colitis. Scand J Gastroenterol 2007, 42:1312-1320

37. Cui G, Olsen T, Christiansen I, Vonen B, Florholmen J, Goll R: Improvement of real-time polymerase chain reaction for quantifying TNF-alpha mRNA expression in inflamed colorectal mucosa: an approach to optimize procedures for clinical use. Scand J Clin Lab Invest 2006, 66:249-259

38. Goll R, Olsen T, Cui G, Florholmen J: Evaluation of absolute quantitation by nonlinear regression in probe-based real-time PCR. BMC Bioinformatics 2006, 7:107

39. Schmittgen TD, Livak KJ: Analyzing real-time PCR data by the comparative C(T) method. Nat Protoc 2008, 3:1101-1108

40. Seidelin JB, Bjerrum JT, Coskun M, Widjaya B, Vainer B, Nielsen OH: IL-33 is upregulated in colonocytes of ulcerative colitis. Immunol Lett 2010, 128:80-85

41. Beltran CJ, Nunez LE, Diaz-Jimenez D, Farfan N, Candia E, Heine C, Lopez F, Gonzalez MJ, Quera R, Hermoso MA: Characterization of the novel ST2/IL-33 system in patients with inflammatory bowel disease. Inflamm Bowel Dis 2010, 16:1097-1107

42. Wang J, Dodd C, Shankowsky HA, Scott PG, Tredget EE: Deep dermal fibroblasts contribute to hypertrophic scarring. Lab Invest 2008, 88:1278-1290

43. Rajkumar VS, Shiwen X, Bostrom M, Leoni P, Muddle J, Ivarsson M, Gerdin B, Denton CP, Bou-Gharios G, Black CM, Abraham DJ: Platelet-derived growth factor-beta receptor activation is essential for fibroblast and pericyte recruitment during cutaneous wound healing. Am J Pathol 2006, 169:2254-2265

44. Nakhaei P, Genin P, Civas A, Hiscott J: RIG-I-like receptors: sensing and responding to RNA virus infection. Semin Immunol 2009, 21:215-222

45. Matsumoto M, Kikkawa S, Kohase M, Miyake K, Seya T: Establishment of a monoclonal antibody against human Toll-like receptor 3 that blocks double-stranded RNA-mediated signaling. Biochem Biophys Res Commun 2002, 293:1364-1369

46. Sugiura $H$, Ichikawa $T$, Koarai $A$, Yanagisawa $S$, Minakata $Y$, Matsunaga K, Hirano T, Akamatsu K, Ichinose M: Activation of Tolllike receptor 3 augments myofibroblast differentiation. Am J Respir Cell Mol Biol 2009, 40:654-662

47. Hellstrom M, Gerhardt H, Kalen M, Li X, Eriksson U, Wolburg H, Betsholtz C: Lack of pericytes leads to endothelial hyperplasia and abnormal vascular morphogenesis. J Cell Biol 2001, 153:543-553

48. Hinz B, Phan SH, Thannickal VJ, Galli A, Bochaton-Piallat ML, Gabbiani G: The myofibroblast: one function, multiple origins. Am J Pathol 2007, 170:1807-1816

49. Hinz B, Mastrangelo D, Iselin CE, Chaponnier C, Gabbiani G: Mechanical tension controls granulation tissue contractile activity and myofibroblast differentiation. Am J Pathol 2001, 159:1009-1020

50. Vijay-Kumar M, Wu H, Aitken J, Kolachala VL, Neish AS, Sitaraman SV, Gewirtz AT: Activation of toll-like receptor 3 protects against DSS-induced acute colitis. Inflamm Bowel Dis 2007, 13:856-864

51. Cario E, Podolsky DK: Differential alteration in intestinal epithelial cell expression of toll-like receptor 3 (TLR3) and TLR4 in inflammatory bowel disease. Infect Immun 2000, 68:7010-7017

52. Hampe J, Schreiber S, Shaw SH, Lau KF, Bridger S, Macpherson AJ, Cardon LR, Sakul H, Harris TJ, Buckler A, Hall J, Stokkers P, van Deventer SJ, Nurnberg P, Mirza MM, Lee JC, Lennard-Jones JE, Mathew CG, Curran ME: A genomewide analysis provides evidence for novel linkages in inflammatory bowel disease in a large European cohort. Am J Hum Genet 1999, 64:808-816

53. Del Zotto B, Mumolo G, Pronio AM, Montesani C, Tersigni R, Boirivant M: TGF-beta1 production in inflammatory bowel disease: differing production patterns in Crohn's disease and ulcerative colitis. Clin Exp Immunol 2003, 134:120-126

54. Ulloa L, Doody J, Massague J: Inhibition of transforming growth factor-beta/SMAD signalling by the interferon-gamma/STAT pathway. Nature 1999, 397:710-713

55. Desmouliere A, Rubbia-Brandt L, Abdiu A, Walz T, Macieira-Coelho A, Gabbiani G: Alpha-smooth muscle actin is expressed in a subpopulation of cultured and cloned fibroblasts and is modulated by gamma-interferon. Exp Cell Res 1992, 201:64-73

56. Ishida $\mathrm{Y}$, Kondo $\mathrm{T}$, Takayasu $\mathrm{T}$, Iwakura $\mathrm{Y}$, Mukaida N: The essential 
involvement of cross-talk between IFN-gamma and TGF-beta in the skin wound-healing process. J Immunol 2004, 172:1848-1855

57. Francoeur C, Bouatrouss Y, Seltana A, Pinchuk IV, Vachon PH, Powell DW, Sawan B, Seidman EG, Beaulieu JF: Degeneration of the pericryptal myofibroblast sheath by proinflammatory cytokines in inflammatory bowel diseases. Gastroenterology 2009, 136:268-277 e263

58. Leeb SN, Vogl D, Gunckel M, Kiessling S, Falk W, Goke M, Scholmerich J, Gelbmann CM, Rogler G: Reduced migration of fibroblasts in inflammatory bowel disease: role of inflammatory mediators and focal adhesion kinase. Gastroenterology 2003, 125:1341-1354

59. Lin SL, Kisseleva T, Brenner DA, Duffield JS: Pericytes and perivascular fibroblasts are the primary source of collagen-producing cells in obstructive fibrosis of the kidney. Am J Pathol 2008, 173:1617-1627
60. Humphreys BD, Lin SL, Kobayashi A, Hudson TE, Nowlin BT, Bonventre JV, Valerius MT, McMahon AP, Duffield JS: Fate tracing reveals the pericyte and not epithelial origin of myofibroblasts in kidney fibrosis. Am J Pathol 2010, 176:85-97

61. Soderholm JD, Olaison G, Peterson KH, Franzen LE, Lindmark T, Wiren M, Tagesson C, Sjodahl R: Augmented increase in tight junction permeability by luminal stimuli in the non-inflamed ileum of Crohn's disease. Gut 2002, 50:307-313

62. Gitter AH, Wullstein F, Fromm M, Schulzke JD: Epithelial barrier defects in ulcerative colitis: characterization and quantification by electrophysiological imaging. Gastroenterology 2001, 121:1320-1328

63. Froslie KF, Jahnsen J, Moum BA, Vatn MH: Mucosal healing in inflammatory bowel disease: results from a Norwegian populationbased cohort. Gastroenterology 2007, 133:412-422 